心理量分布図による街路空間の雾囲気と指摘エレメントの相関分析 一街路空間に㧍ける「気配」の研究 (その 2$)-$

\title{
A CORRELATION ANALYSIS OF AN ATMOSPHERE AND INDICATION ELEMENT OF STREET SPACE BY PSYCHOLOGICAL QUANTITY DISTRIBUTION FIGURE \\ -Study of kehai in urban street spaces (Part 2)-
}

\author{
積田 洋*, 関戸洋子**, 濱本紳平*** \\ Hiroshi TSUMITA, Yoko SEKIDO and Shimpei HAMAMOTO
}

\begin{abstract}
The purpose of this study is to clarify kehai* on streets. In psychological experiments, subjects walked both sides of a street and answered questionnaires at points $200 \mathrm{~m}$ apart on 11 streets. The questionnaires used a semantic differential value that consisted of seventeen pairs of adjectives (such as lively/ lonely, multiple/ monotone, and healing/ stressful) and seven steps of evaluation. The study conducted principal-component-analysis of the subjects' answers. The result indicated two to four elements that represent each street. The study also created psychological quantity figures and analyzed them.
\end{abstract}

${ }^{*}$ Kehai means sequential extension of atmosphere.

Keywords : Kehai, street spaces, principal-component-analysis, psychological quantity figures, indication element, correlative analysis 気配、街路空間、主成分分析、心理量分布図、指摘エレメント、相関分析

\section{1. 研究目的}

街路空間のなかで、ある種の気配や雰囲気を捉えることができる。 このような雾囲気は街路空間を構成している様々なエレメント、例 えば建築、街路樹、看板等がその位置的関係も含めて複合的に組み 合わされることにより生み出されていると考えられる。これら街の 雾囲気はひとつの雾囲気で作られているのではなく、様々な雲囲気 が都市空間に存在し、それらが複合し連続的なつながりを持つこと で、その街路独自の空間を構成している。

前報文1)に引き続き、本研究では「雾囲気」とはその場でのある感 じ、「兆し」とはその場の雲囲気のみならず次なる空間を予感させる もの、「象徴」とは街路空間のキーエレメントとなり広域に影響を与 えるもの、さらに、「エレメント」とは場の要素と定義し、これらの 雰囲気・兆し・象徵といった全てを包含するところの気配について、 実際の街路空間における物理的かつ心理的な構成のあり様を把握す ることにより、街路空間の「気配」に迫ろうとするものである。

なお、前報では典型的な特徴をもつ街路空間を客観的に選び、実 際の街路空間において、人々の印象に残る様々なエレメントをシー クエンシャルに把握するために行った〈指摘量分析〉について報告 した。まず、(1)用途、街路形態、街路に接する建築群のスカイライ ンの変化など、6アイテムにより街路架間を 11 の典型的なタイプ
として分類し、街路空間において印象的に残るもの、あるいは特徴 的と思われるエレメント・構成要素について、指摘されたエレメン

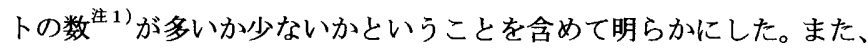
(2)エレメントの指摘数による指摘量ドットマップ図 ${ }^{\text {22) }}$ の分析では、 調查地点の近距離のみならず、中・遠距離のエレメント ${ }^{\text {住3) }}$ が指摘 されることが数量的に示された。これらの構成がシークエンシャル な変化から街路独自の気配を生む要因となることを示した。さらに、 (3)エレメントの構成を《近》《中》《遠》《不特定》エレメント注3) $4 つ に$ 分け、分析した結果、街路空間のエレメント構成を典型的な 6 タイプ洋4) として示した。

本報では、街路空間の心理的構成を把握するために、〈心理量分析〉 について報告する。(1街路空間のシークエンシャルな雲囲気を心理 量分布図（主成分別）として示し、エレメントの指摘の様態を図示 した指摘量ドットマップ図と併記し、分析を行う。さらに、(2)前報 における指摘エレメントの構成の 6 タイプと本報における心理量と の相関関係を分析し、街路空間の気配について物理面、心理面から 明らかにする。

本研究に関連する研究として、筆者らの街路空間やオープンスペー スを対象とした研究文2)，文3)，文4)，文5) がある。また、松本直司ら文6) の「住宅地における建築群の構成計画に関する基礎的研究」では模

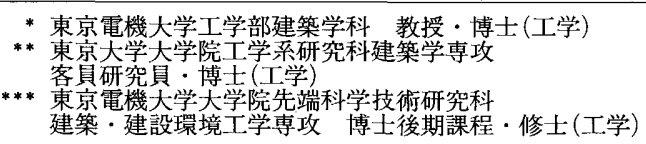

Prof., Dept. of Architecture, Faculty of Engineering, Tokyo Denki Univ., Dr. Eng. Researcher, Department of Architecture, Graduate School of Engineering, The University of Tokyo, Dr. Eng.

Graduate Student, Dept. of Architecture, Civil and Environmental Engineering, Tokyo Denki Univ., M. Eng. 
型とファイバースコープを用いることで、複数の地点で心理実験を 行い、空間の視覚的効果を多面的にとらえ、その構造を把握するた めに心理的評価の強弱を心理等高線で表し、分析を行っている。松 本らが模型を用いたのに対して、本研究では実際の街路空間で実験 を行っている点において異なる。また、参道空間の研究として筆者

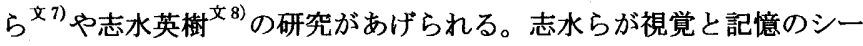
クエンスを扱ったのに対して、本研究では記憶ではなく現場で感じ られる気配そのものについて解明する点において、他とは異なるも のである。

\section{2. 心理量分析の概要}

実験の調查対象地区については、前報に記載したクラスター分析 (最長距離法) により分類した 11 タイプ（C 1 ～C 11 1) から、各 タイプを代表する街路空間として、表 3 に示す通り、銀座、国立、 六本木、山手、渋谷、表参道、鎌合、秋葉原、馬車道、新宿、巣鴨 の 11 街路（調查対象距離 $0.8 \sim 2.0 \mathrm{k} \mathrm{m}$ ）を選定した。街路空間 の雰囲気を定量的に捉えるためS D法による心理評価実験を行った。 S D法の心理評定尺度については、筆者らの一連の街路空閒の研究 文2）基に街路空間の心理評価構造である 12 心理因子軸を選定し、 さらに様々な雾囲気をもつ街路空間の気配を評価するために必要と 判断した 5 心理評定尺度；虑される感じーストレスを感じる、聖な る感じ一俗な感じ、健全な感じ一怪しげな感じ、色気のある感じー そっけない感じ、人間的スケールー非人間的スケール、を新たに加

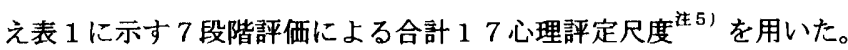

本実験では、調查対象地区の㞣囲気の移り変わりを詳細に把握す るため、実験を行う地点をいくつかに分けて行うことにした。調查 地点は街路の佘囲気を視覚的に捉えやすい交差点とした。また、調 查地点間距離は上記の調查対象地区において、交差点から交差点ま での距離が概ね2 $200 \mathrm{~m}$ で共通して区切ることができた。そこで、 本研究の調查地点間距雄を約 $200 \mathrm{~m}$ とした。なおこれは既に報告 した〈指摘法実験〉と同地点である。被験者は建勧学科の学生 10

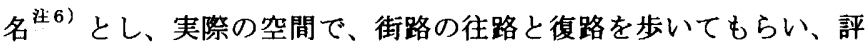
定用紙に記入してもらった。評定用紙は、地点ごとに配布し、被験 者の回答後は直ちに回収し、記入漏れなどを見なおし、その場で訂 正を行った。

\section{3．心理量分布図（主成分別）による分析}

各調査対象地区の心理評価の特徴を明らかにするため、各地点を 通して得られた 17 心理評定尺度の心理量の平均値（各地区各地点 での被験者 10 名、往路復路分の計 20 名分の 7 段階心理評価を合 計し人数分で割ったもの) 社7)をもとに、調査対象地区ごとに主成 分分析を行った（表 2 )。

その結果、各調查対象地区の心理評価の構成からその街路を代表す る特徵的な変化を示す心理評定尺度が得られ、表 4 に示す $2 \sim 4 つ$ の主成分（固有值 1 以上）から代表心理評定尺度を抽出した。この 代表心理評定尺度に基づき心理量分布図（主成分別） ${ }^{\text {住8) }}$ を作成した。 作図方法については、図 2 に示すように、まず各地点における心理 評定尺度の平均值 (心理量) を横軸、地点を縦軸としたシークエン スな変化が表記できる折れ線グラフを作成し、次にその心理量数值
を 0.5 刻みに地図上に投影後、同じ数值間を楕円でつなぐことによ り、心理量分布図（主成分別）を作成した。これは対象となる街路 空間ごとに心理量の変化を視覚的にわかりやすく表現したものであ る。(調查地点を含まない小路や地区については、この限りではない。) さらに、前報での指摘実験により得られた指摘量ドットマップ図も 心理評価と物理的構成との関係を合わせて比較するため併記する。

【銀座】全体的に見て銀座は、G地点の首都高速により空間が分断さ れ、(1)日比谷公園の緑地带、(2)有楽町マリオンを中心としたまとま

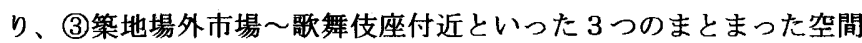
で構成されている。第 1 主成分（以下（第 1 ）と略）の〈健全な感 じ〉のまとまりが I 地点、(心理評価 6)（以下（評価 6）と略）を頂 点として F 地点付近まで拡がっている。これは《近》エレメントと して指摘される日比谷公園、有楽町マリオン、皇居、さらに街路樹 や緑といった《不特定》エレメントにより菞囲気を作り出している。 （第 2 ）の〈豊かな感じ〉のまとまりが街路全体的に見られる。しか し、C、E、H地点でこの雲囲気が分断されている。その要因として、

\begin{tabular}{|c|c|}
\hline \multicolumn{2}{|c|}{ 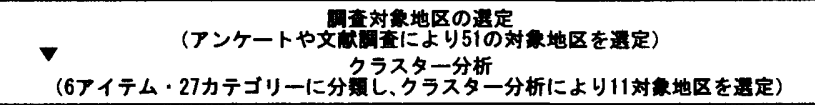 } \\
\hline$\nabla$ & $\nabla$ \\
\hline 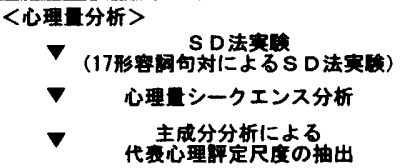 & 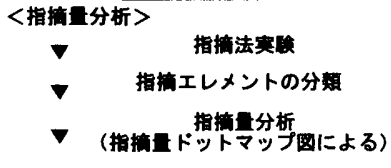 \\
\hline$\nabla \quad \begin{array}{l}\text { 心理贯分布图による分析 } \\
\text { (空而形成タイナの抽出) }\end{array}$ & 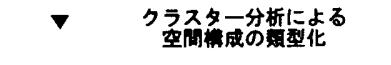 \\
\hline
\end{tabular}

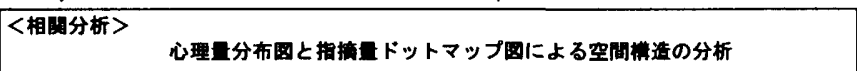

图 1 本研究のフロー

1 銀座各地点の心理

\begin{tabular}{|c|c|c|c|c|c|c|c|c|c|c|c|c|}
\hline & 心理押定尺度 & A & $B$ & C & $D$ & $E$ & $F$ & G & $\mathrm{H}$ & & 平均 & 筒差 \\
\hline 1 & にぎやかな感じーさびしい感じ & 4.6 & 4.9 & 2.6 & 5.4 & & 6.8. & 6.1 & & & & \\
\hline 2 & ワォーマルな感じーカジュアルな感じ & 8 & 2.4 & & & 3.2 & & $y$ & & & 3.9 & \\
\hline 3 & 多様な感じ－画一的な感じ & 4.9 & 9 & 3.4 & 5.9 & 5.6 & 6.2 & 6 & 4.2 & 5.1 & 5.2 & .0 \\
\hline 4 & 新しい感じー古い感し & 2 & 2.6 & 0.2 & 2.9 & 4. 4 & $\{3,4\}$ & 6 & 4.8 & 3.9 & 4.3. & $|1.2|$ \\
\hline 5 & 健全な感じー怪しげな感じ & 4.4 & 4.6 & 5.1 & 4.4. & 4.1. & 4.5 & 4.9 & 4,9 & 6.6 & 4.8 & 0.7 \\
\hline 6 & 直線的な感じ一折れ曲がった感じ & 5,5 & 5.9 & 5.9 & 5.6 & 5.9 & 6.4 & 5.2 & 4.6 & 6.2 & 5.7 & 0.5 \\
\hline 7 & さわやかな感じーうっとうしい琙じ & 4. & 4 & 4. 4 & 4.2 & 3.7 & 4.5 & 4.2 & 3.7 & 6.6 & 4.4 & 0.9 \\
\hline 8 & 人間的スケールー非人間的スケール & 4.9 & 4.9 & & 3.6 & 3.7 & 3.4 & 2,1 & .0 & 2.9 & 3.3 & \\
\hline 9 & 豪華な感じ一頁素な感じ & 2.9 & 2.3 & 3.5 & 5.7 & 4. $4 \mathrm{ts}$ & 5,8 & 5,6 & 4,4 & 4.4 & 4.3 & \\
\hline 10 & 䄇される感じーストレスを感じる & 3.8 & 3.6 & 3.2 & 4.4 & 3,3, & 3.5 & 3,6 & 2.7 & & 3.8 & 0.9 \\
\hline & 緑の多い感じー緑の少ない感し & 3.1 & & 2.9 & 2.9 & & & 2.9 & 3.4 & & 3.3 & \\
\hline 112 & 聖なる感じ一俗な感じ & 2.9 & 2.9 & 3.2 & 2.4 & 2.2 .2 & & 2.4 & 3.4 & 5.2 & 3.0 & \\
\hline 13 & 一期待感のない感じ & 3.9 & 4. 3. & 9 & 4.6 & 4.9 & 311 & 6 & 4.5 & 1 & 4.6 & 0.9 \\
\hline 14 & 豊かな感じー之しい感じ & 4 & 4 & 2.6 & 5.1 & 4.3 & 4.9 & 4.9 & 3.4 & 5.7 & 4.3 & \\
\hline 15 & みのある感じーよそよそしい感し & 5.3 & 5.3 & 8 & 5,1 & 4.5 & 4.6 & 4.6 & & 4.8 & & \\
\hline 16 & えじーばらばらな感じ & 2.6 & & & 2.2 & 2.8 & 8 & & 3.5 & 1.9 & 3.2 & \\
\hline & 一そっけない感 し & & & & & & & & & & & \\
\hline
\end{tabular}

表 2 銀座における心理の主成分分析

\begin{tabular}{|c|c|c|c|c|c|c|}
\hline & 心理評定尺度 & 第 1 & 策 2 & 第3 & 第 4 & 第 5 \\
\hline 5 & 健全な感じ一怪しげな感じ & 0.968 & -0.008 & 0.009 & -0.152 & -0.151 \\
\hline 12. & 聖なる感じ一俗な感じ & 0.942 & -0.087 & -0.211 & -0.148 & -0.052 \\
\hline 7 & さわやかな感じーうっとうしい感じ & 0.931 & 0.321 & -0.102 & 0.109 & -0.025 \\
\hline 11 & 緑の多い感じー緑の少ない感じ & 0.895 & 0.129 & -0.282 & -0.290 & -0.064 \\
\hline 16 & 統一感のある感じーばらばらな感じ & 0.856 & 0.028 & 0.386 & 0.130 & $-0,246$ \\
\hline 2 & フォーマルな感じーカジュアルな感じ & 0.742 & -0.239 & 0.384 & 0.105 & 0.423 \\
\hline 10 & 䆜される感じーストレスを感じる & 0.711 & 0.555 & -0.336 & -0.056 & 0.168 \\
\hline 1 & にぎやかな感じーさびしい感じ & -0.628 & 0.5121 & 0.429 & -0.123 & -0.066 \\
\hline 14 & 豊かな感じーそしい感じ & 0.287 & 0.946 & 0.015 & -0.097 & 0.093 \\
\hline 17 & 色気のある感じーそっけない感じ & -0.080 & 0.941 . & 0.226 & 0.165 & 0.158 \\
\hline 3 & 多様な感じ一再一的な感じ & -0.335 & 0.916 & -0.035 & -0.001 & -0.118 \\
\hline 13 & 期待感のある感じー期待感のない感じ & -0.005 & 0.796 & 0.441 & -0.320 & -0.226 \\
\hline 15 & 親しみのある感じーよそよそしい感じ & $-0,176$ & 0.780 & -0.560 & -0.007 & $-0,082$ \\
\hline 4 & 新しい感じー古い感じ & 0.093 & -0.114 & 0.883 & 0.204 & -0.351 \\
\hline 8 & 人間的スケール－非人間的スケール & -0.394 & 0.258 & -0.841 & 0.059 & -0.016 \\
\hline 9 & 毫華な感じ一斦素な感じ & 0.019 & 0.529 & 0.789 & 0,061 & 0.340 \\
\hline 6 & 直線的な感じー梊れ曲がった感じ & 0.319 & 0.341 & -0.289 & 0.814 & -0.119 \\
\hline & 固有值 & 6.183 & 5.097 & 3.456 & 1.039 & 0.662 \\
\hline & 寄与率 & 0.363 & 0.299 & 0.203 & 0.061 & 0.038 \\
\hline & 累積䨐与率 & 0.363 & 0.663 & 0.866 & 0.928 & 0.967 \\
\hline
\end{tabular}


C地点では、《近》エレメントの銀行やオフィスビル等の指摘が見ら れる。この地点では印象的なエレメントが少なく、どこにでも遍在 するエレメントが多く指摘されている。つまり、一般的な銀行や才 フィスビルが持つ無表情なファサードが集合体として指摘されるこ とで、街路空間の中で「地」エレメント ${ }^{\text {年) }}$ となり、連続する気配 を分断し〈乏しい感じ〉を生み出している。（第3）の〈新しい感じ〉 がG地点（評価 5.5）を中心としたまとまりが見られる。反対に〈古 い感じ〉のまとまりが D地点（評価 3）の歌舞伎座付近、A地点（評 価 3）の策地場外市場付近を中心として形成されている。Aから I 地 点方向へ行くに従い、全体的に新しさの雲囲気が盛り上がっている。 $\mathrm{G}$ 地点においては特に顕著である。指摘量ドットマップ図から見て も、銀座の街路空間の中で有楽町マリオンは、強いインパクトを与 える「図」エレメント ${ }^{\text {i⿱丶万) }}$ として近・中・遠のどの距離からも多く指 摘され、銀座のランドマークとして存在している。これが健全な感じ・ 豊かな感じ・新しい感じ（各評価 4.5）を生み出すエレメントとして、 様々な地点にその「気配」を示しているといえる（図 3)。

【国立】全体的に見て国立は、(1)国立駅前広場から商店街への空間、
(2)一橋大学通りの街路樹空間、(3)谷保駅周辺の住宅地付近の 3 つの まとまった空間で構成されている。(第 1) では、《不特定》ェレメ ントである一橋大学通りの街路樹、植栽、歩道等の影響により、C 地点（評価 5）を中心とし、Aから F地点付近までかなり大きな〈豊 かな感じ〉の雾囲気のまとまりを形成している。一方、G地点を境に、 $\mathrm{H}$ から $\mathrm{J}$ 地点の谷保駅へ向かう空閒では、街路樹や緑等の《不特定》 エレメントが礞的に少なくなることで〈之しい感じ〉という雾囲気 を形成している。（第 2）では、〈にぎやかな感じ〉のまとまりが $\mathrm{A}$ 地点（評価 5.5）を中心にAからC地点まで拡がっている。CからA 地点へ、にぎやかな雲囲気の盛り上がりが見られる。これは J R 国 立駅前のバスやタクシーのロータリー、駅を利用する人々の流れな ど様々なアクティビィティを喚起させるエレメントが、駅前空間に 向かうにつれて増加し、連続し、指摘されることが要因である。(第 3 ) では、全体的に〈人間的スケール〉のまとまりを形成している。こ の街路の街路樹や住宅等のエレメントには共通したスケール感があ る。しかし、G地点で、そのスケール感を大きく超えたC高層マンショ ンが出現する事で、この街のスカイラインに大きな変化をもたらし、

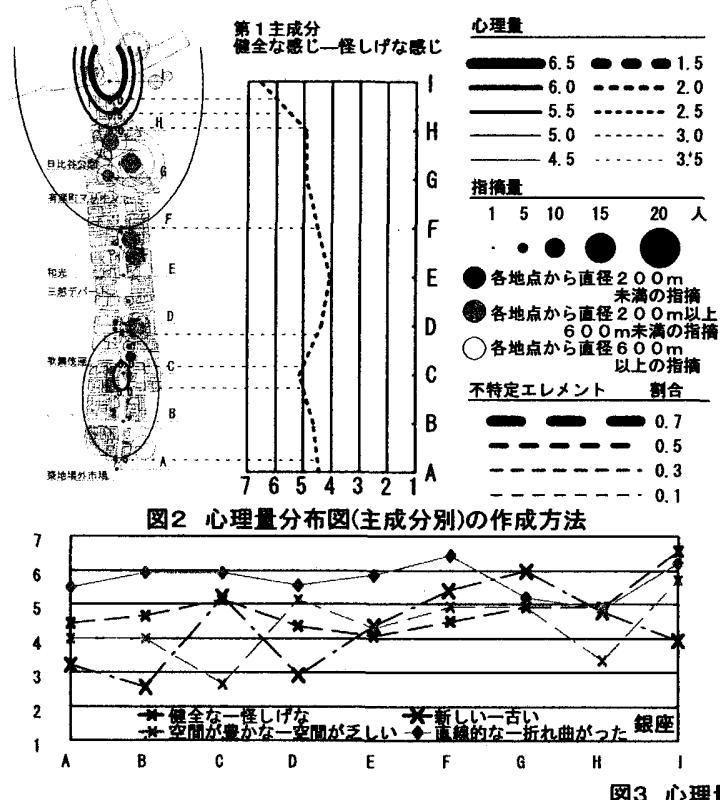

銀座 $\mathrm{O}$

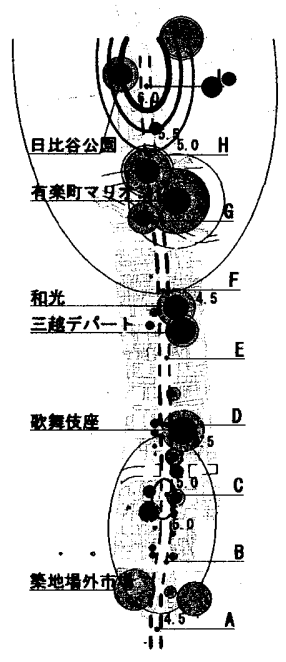

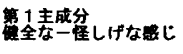

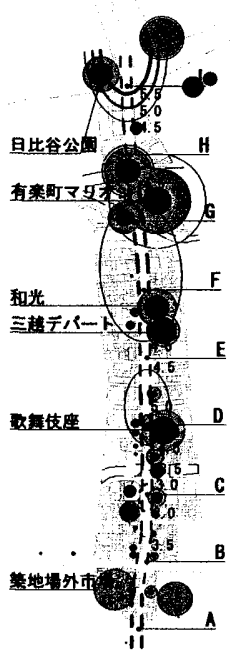

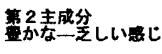

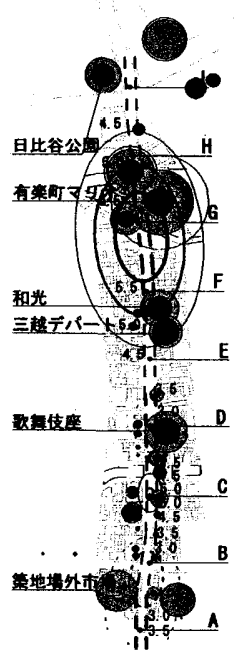

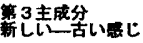

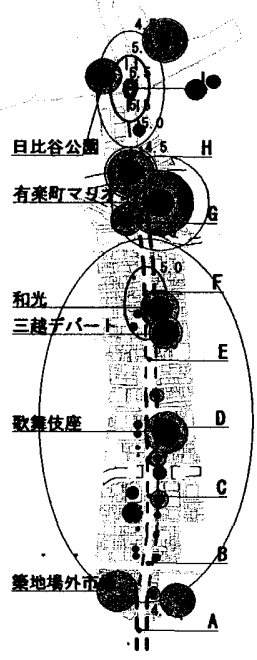

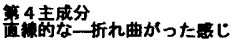

表 3 解㚗対象地区の概要表

\begin{tabular}{|c|c|c|c|c|c|c|c|c|c|c|c|c|c|c|c|c|}
\hline \multirow{2}{*}{ Cluster } & \multirow{2}{*}{ 対象地区 } & \multirow{2}{*}{ 街路 } & \multirow{2}{*}{ 区間 } & \multirow{2}{*}{ 距部 (䄪) } & \multirow[b]{2}{*}{ 地点数 } & \multirow[b]{2}{*}{ 用途 } & \multicolumn{2}{|c|}{ 連㭏的要表 } & \multicolumn{2}{|c|}{ 鹪路形筧 } & \multicolumn{2}{|c|}{ スカイライン } & \multirow[b]{2}{*}{ 道路 } & \multirow[b]{2}{*}{ 間口 } & \multirow[b]{2}{*}{ 年/月 } & \multirow[b]{2}{*}{ 天坟 } \\
\hline & & & & & & & 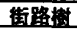 & 空板 & 折典 & 坂 & 高さ & 形背 & & & & \\
\hline C1 & 銀座 & 晴海通り & 築地〜日比谷 & $1.6 \mathrm{~km}$ & 9 & 繁華街 & & ? & & & 高厧 & 複雑 & 広 & 広 & $00 / 11$ & 晴狆 \\
\hline $\mathrm{C} 2$ & 国立 & 大学通り & 国立駅南口～谷保駅 & $1.8 \mathrm{~km}$ & 10 & 住宅地. & e & & & & 低眉 & 单調 & 広 & 広 & $02 / 7$ & 晴れ \\
\hline $\mathrm{C} 3$ & 六本本 & 外苑東通口 & 乃木坂～飯倉 & $1.8 \mathrm{~km}$ & 10 & 繁華街 & & e & e & 0 & 中層 & 複雑 & 広 & 広 & $01 / 8$ & 晴れ \\
\hline $\mathrm{C} 4$ & 山手 & 山手本通り & 地藏坂上〜港の見える丘公園 & $1.4 \mathrm{~km}$ & 8 & 住宅地 & & & & 0 & 低層 & 単調 & 狭 & 広 & $02 / 8$ & 睛れ \\
\hline $\mathrm{C} 5$ & 漇谷 & 文化村通 & 八千公前～能楽堂 & $0.8 \mathrm{~km}$ & 5 & 繁華街 & & 0 & 8 & 0 & 中層 & 複雜 & 狭 & 広 & $01 / 8$ & 晴 $れ$ \\
\hline C6 & 表参道 & 表参道 & 代々木〜青山 & $1.8 \mathrm{~km}$ & 10 & 繁華街 & 웅 & & & 0 & 中層 & 単調 & 広 & 狭 & $00 / 11$ & 晴狆 \\
\hline C7 & 鉡會 & 若宮大路 & 海崖通り〜八幡宫 & $1.8 \mathrm{~km}$ & 10 & 歴史街 & e & & & 0 & 低層 & 単調 & 広 & 狭 & $01 / 11$ & 晴礼 \\
\hline $\mathrm{C} 8$ & 秋葉原 & 中央通り & 秋葉原〜上野 & $2.0 \mathrm{~km}$ & 11 & 繁華街 & & 0 & & 0 & 中層 & 単調 & 広 & 狭 & $00 / 8$ & 晴杂 \\
\hline C9 & 馬車道 & 馬車道 & 関内酑〜新港字頭 & $1.2 \mathrm{~km}$ & 7 & 商店街 & & 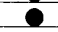 & & & 中層 & 単調 & 狭 & 狭 & $02 / 7$ & 晴れ \\
\hline $\mathrm{C} 10$ & 新宿 & 歇舞伎町 & 新宿駅東口～職安通り & $0.8 \mathrm{~km}$ & 5 & 歓楽街 & & & 0 & & 中層 & 複雑 & 狭 & 狭 & $01 / 10$ & 晴れ \\
\hline C11 & 宩鴨 & 地藏藏通り & 巢鴨駅〜庚电塚駅 & $1.2 \mathrm{~km}$ & 7 & 商店街 & & & & & 低層 & 爯调 & 狭 & 狭 & $02 / 8$ & 睛れ \\
\hline
\end{tabular}

表 4 各地区の代表心理評定尺度

\begin{tabular}{|c|c|c|c|c|}
\hline 地区 & 第1主戚分 & 㝢2主成分 & 第3主成分 & 第4主成分 \\
\hline 銀座 & 健全な感じー怪しげな感じ 0.968 & (空間が)曹かな感じ-そしい感じ 0.946 & 新しい感じー古い感じ 0.883 & 直線的な感じ-折れ曲がった感じ 0.814 \\
\hline 国立 & 空間が豊かな感じ-空間がそしい感じ0.973 & にぎやかな感じーさびしい感じ 0.935 & 人間的スケールー非人間的スケール 0.715 & - \\
\hline 六本木 & にきやかな感じ-さびしい感じ -0.981 & 人間的スケール-非人間的スケール 0.893 & 期待感のある感じ-ない感じ 0.784 & - \\
\hline 山手 & にぎやかな感じ-さびしい感じ 0.927 & 聖なる感じ-俗な感じ0.856 & 統一感のある感じーばらばらな感じ -0.921 & - \\
\hline 渉谷 & 密される感じーストレスを感じる 0.988 & 色気のある感じーそっけない感じ 0.927 & - & - \\
\hline 表参道 & 聖なる感じー俗な感じ 0.958 & フォーマルな感じーカジュアルな感じ -0.697 & - & 人間的スケールー非人間的スケール -0.778 \\
\hline 鉡倉 & (空間が)豊かな感じ-そしい感じ 0.968 & にぎやかな感じーさびしい感じ 0.891 & 親しみのある感じーよそよそしい感じ 0.671 & - \\
\hline 秋葉原 & 䯢される感じーストレスを感じる 0.975 & 親しみのある感じーよそよそしい感じ 0.894 & 新しい感じ-古い感じ 0.888 & - \\
\hline 馬車道 & 緑が多い感じ-緑が少ない感じ -0.961 & フォーマルな感じーカジュアルな感じ 0.851 & 色気のある感じーそつけない感じ 0.975 & 健全な感じ-怪しげな感じ0.648 \\
\hline 新宿 & にぎやかな感じ-さびしい感じ 0.995 & (空間が)豊かな感じ-そしい感じ 0.891 & - & - \\
\hline 笨呞 & 粒一感のある感じーばらばらな感じ -0.947 & にぎやかな感じーさびしい感じ 0.974 & 直線的な感じ-折れまがった感じ 0.791 & うっとうしい感 \\
\hline
\end{tabular}


この空間のシークエンシャルな䨌囲気を分断している。指摘量ドッ トマップ図から見ても国立の街路空間の中で《不特定》エレメント である街路樹の指摘が多く、国立の特徴的なエレメントであるとい える。これらが豊かな感じ・人間的スケール（各評価 4.5～5）を生 み出すエレメントとして空間に一体感を作っている（図 4)。

【六本木】全体的に見て、六本木は(1) T O T O ビル付近、(2)六本木交

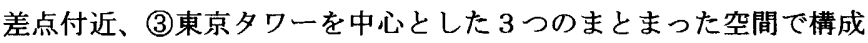
されている。（第 1）では、F 地点（評価 6.5）の六本木交差点周辺 のアマンド、首都高速、オーロラビジョン、看板等の《不特定》エ レメントの集合して指摘されることで、Dから $\mathrm{G}$ 地点まで〈にぎや かな感じ〉のまとまりを形成している。F地点で街路がくの字に曲 がり、アイストップ空間を生み出している。そのため、《中》エレメ ントの指摘が多く、周辺から F地点一向かい急激に、にぎやかな春 囲気の高まりが生まれている。また、J 地点付近（評価 3.5）では〈さ びしい感じ〉のまとまりが見られる。（第 2 ）の〈非人間的スケール〉 がA地点（評価 2.5）、F、E地点（評価 3）を中心としたまとまり を形成していることが分かる。これは、東京タワーや、首都高速等 のエレメントが強く影響を与えている。（第３）において、東京タワー が指摘できるA地点 (評価 4.5) や、D地点 (評価 4.5)、オーロラビジョ ン、カラオケ店、スイーツ店が指摘される $\mathrm{F}$ 地点（評価 4.5）を中心 に〈期待感がある感じ〉のまとまりがある。指摘量ドットマッブ図 から見ても六本木の街路空間の中で東京タワーのような中・遠距離 からの指摘の多いエレメントは、街路空間のランドマークとして広 域に影響を及ぼし、期待感のある感じ（評価 5)、非人間的スケール(評 価 2.5）という象徴的な「気配」を生み出している(図 4)。

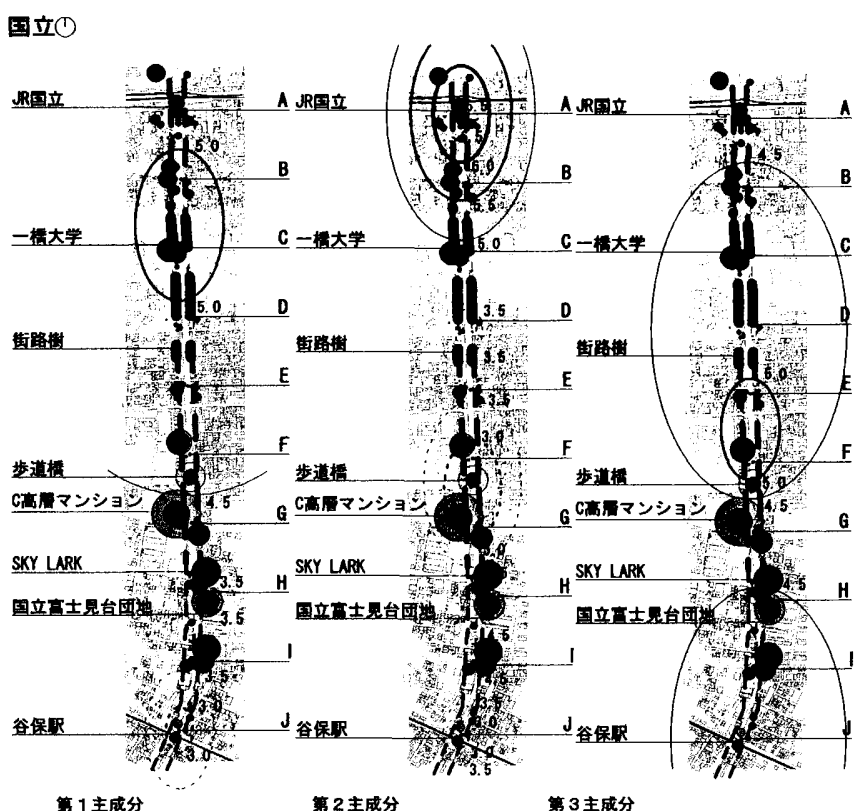

【山手】全体的に見て山手は、高級住宅が建ち並ぶ閑静な住宅街とい う大きなまとまりの中に、A地点のような横浜の港等、《遠》ェレメ ントを見渡せる地点が、数地点街路空間の中に点在することで山手 独自の街路を構成している。（第 1）では、B地点（評価 3.5）、E、 $\mathrm{F}$ 地点（評価 3）を中心にDから G 地点付近まで大きく〈さびしい感 じ〉のまとまりが見られる。しかし、このような雰囲気のまとまり を《遠》エレメントである横浜市街のベイブリッジや大栈橋を見渡 せるA地点（港の見える丘公園）、《遠》エレメントのランドマーク タワーやクインズスクエアが指摘されるH地点で、その〈さびしい 感じ〉のまとまりが分断されている。これは、横浜市街を感じるエ レメントが指摘できること、折れ曲がり空間から丘の頂上付近の視 界が開けた空間に出たことが要因といえる。このような《遠》エレ メントや高低差のある街路形状が影響し、〈さびしい感じ〉を分断し たと考えられる。（第 2）の〈聖なる感じ〉のまとまりが B 地点（評 価 5) の外人墓地、 $\mathrm{F}$ 地点 (評価 5.5) のカトリック教会を中心に拡がっ ている。指摘量ドットマップ図から見ても山手の街路空間の中で《近》 エレメントである外人墓地やカトリック教会が多く指摘されている。 これらのエレメントがその場を中心として、聖なる感じ（評価 4.5 ～5）を生み出寸㞣囲気を作り、周辺の「気配」を形成している。（第 3）では、C、D地点（評価 4.5）を中心に〈統一感のある〉のまと まりが見られる。これは、住宅街という共通した性格のエレメント が集合することで雲囲気を形成している(図 5 )。

【渋谷】全体的に見て渋谷は、文化村を境に、(1)渋谷駅前のにぎやか

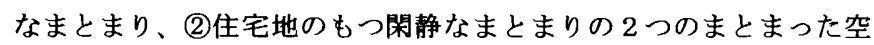
間で構成されている。（第 1 ）では、春囲気のまとまりが大きく二極

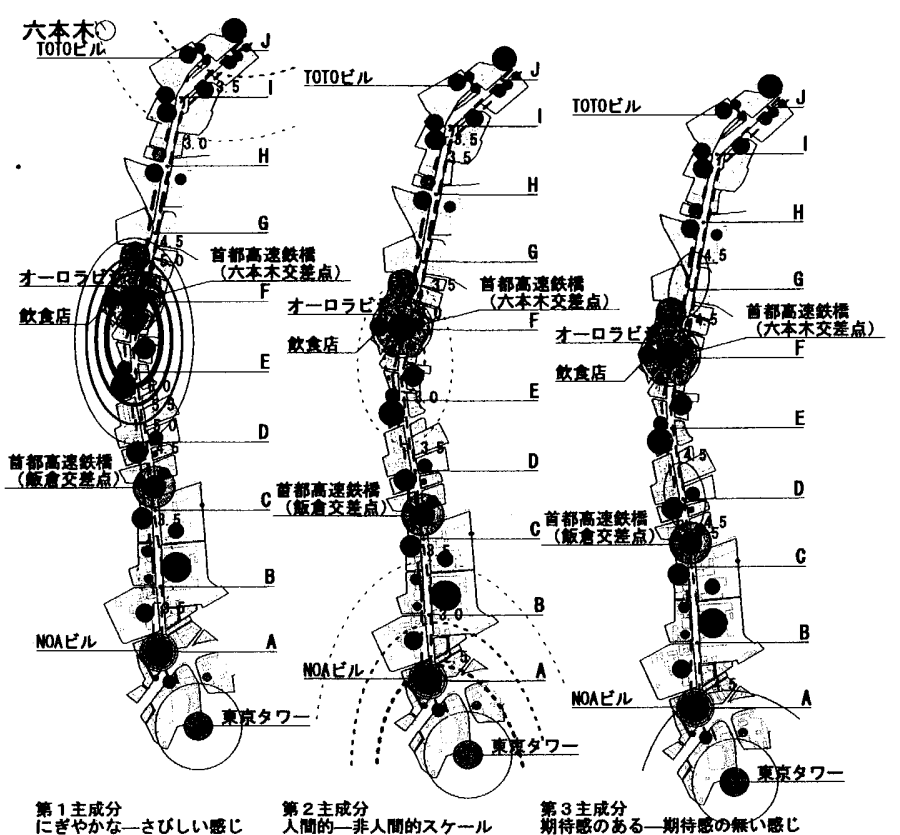

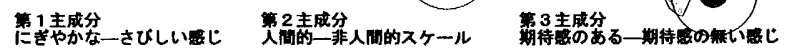

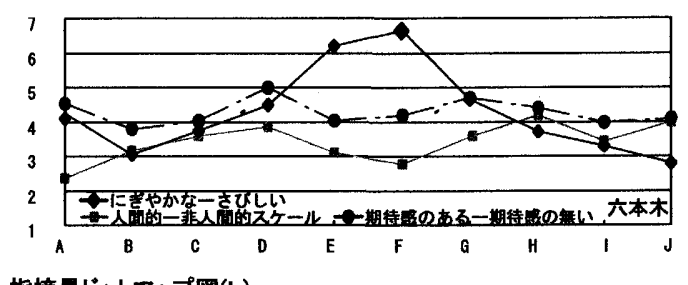

图4 心理量分布図(主成分別)と指摘量ドットマップ図(b) 
化している。A地点（評価 2.5）を中心にC地点付近まで大きく〈ス トレスを感じる〉のまとまりが形成されている。この浩谷駅方面の まとまりは《不特定》エレメントである看板等の指摘が突出して多 い空間であるためだといえる。反対に、E地点（評価 5.5）を中心と した松涛側のまとまりは、〈瘉される感じ〉のまとまりを形成してい る。この地点は《中》《遠》エレメントの指摘がなく、《近》エレメ ントである住宅地や知事官邸等のエレメントが集合として認識され、 その場の癒される感じの雾囲気で「気配」が形成されている。(第 2) では、C、D地点（評価 3.5）を中心として文化村の裹側の雑多な建 物の集合により〈そっけない感じ〉のまとまりが見られる。指摘量ドッ トマップ図から見ても、渋谷の街路空間の中で印象の強い《近》《中》 エレメントである文化村が多く指摘され、これを境に「裏」の空間 である住宅街は、異なった軺囲気を与えている（図 5)。

【表参道】全体的に見て表参道は、D地点の表参道交差点、H地点の 神宮交差点で空間が分断され、(1)根津美術館付近、(2)同潤会アパー

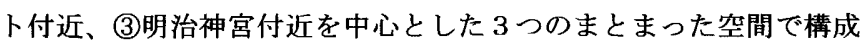
されている。（第 1）では、J 地点（評価 5.5）の明治神宮の緑、代々 木体育館を中心に〈聖なる感じ〉のまとまりがみられる。これは明 治神宮の緑の影響が強い。（第 2）では、A地点（評価 4.5）を中心 に〈フォーマルな感じ〉のまとまりが見られる。これは《近》エレ
メントの根津美術館の影響が大きいといえる。また、 $\mathrm{E}$ 地点（評価 2.5）とG地点（評価 2）を中心にDから J 地点まで〈カジュアルな 感じ〉のまとまりが見られる。これは同潤会アパートやG A P、ラ フォーレ等の店舗のイメージにより、その雲囲気を作り出している といえる。（第 4）では、A地点（評価 5.5）を中心としてAからC 地点まで〈人間的スケール〉のまとまりがある。その要因として、《近》 エレメントである住宅や集合住宅のスケールが影響していると考え られる。しかし、D地点の 246 交差点付近で、複合商業施設や銀 行ビルといった、周辺のスケールを超えたエレメントが集合するこ とで〈非人間的スケール〉のまとまりを形成し、街のシークエンシャ ルな雾囲気を分断している。AからH地点はほぼ《近》エレメント の指摘のみで構成されている。指摘量ドットマップ図から見ても表 参道の街路空間の中でラフォーレ・G A P 等は指摘が多く、カジュ アルな感じ・俗な感じ（各評価 $2 \sim 3.5$ ）、また、根津美術館等はフォー マルな感じ（評価 4.5)、街路樹は人間的スケール（評価 5.5）の雰 囲気を作っている(図 5)。

【鎌倉】全体的に見て鎌倉は、(1)AからC地点の海側のまとまり、(2) EからH地点の参道空間のまとまり、(3) I 、J 地点の八幡宮までの まとまりの3つのまとまった空間で構成されている。（第 1 )では、C、 $\mathrm{D}$ 地点（評価 5)、J 地点（評価 6）を中心として、大きく〈豊かな感じ〉
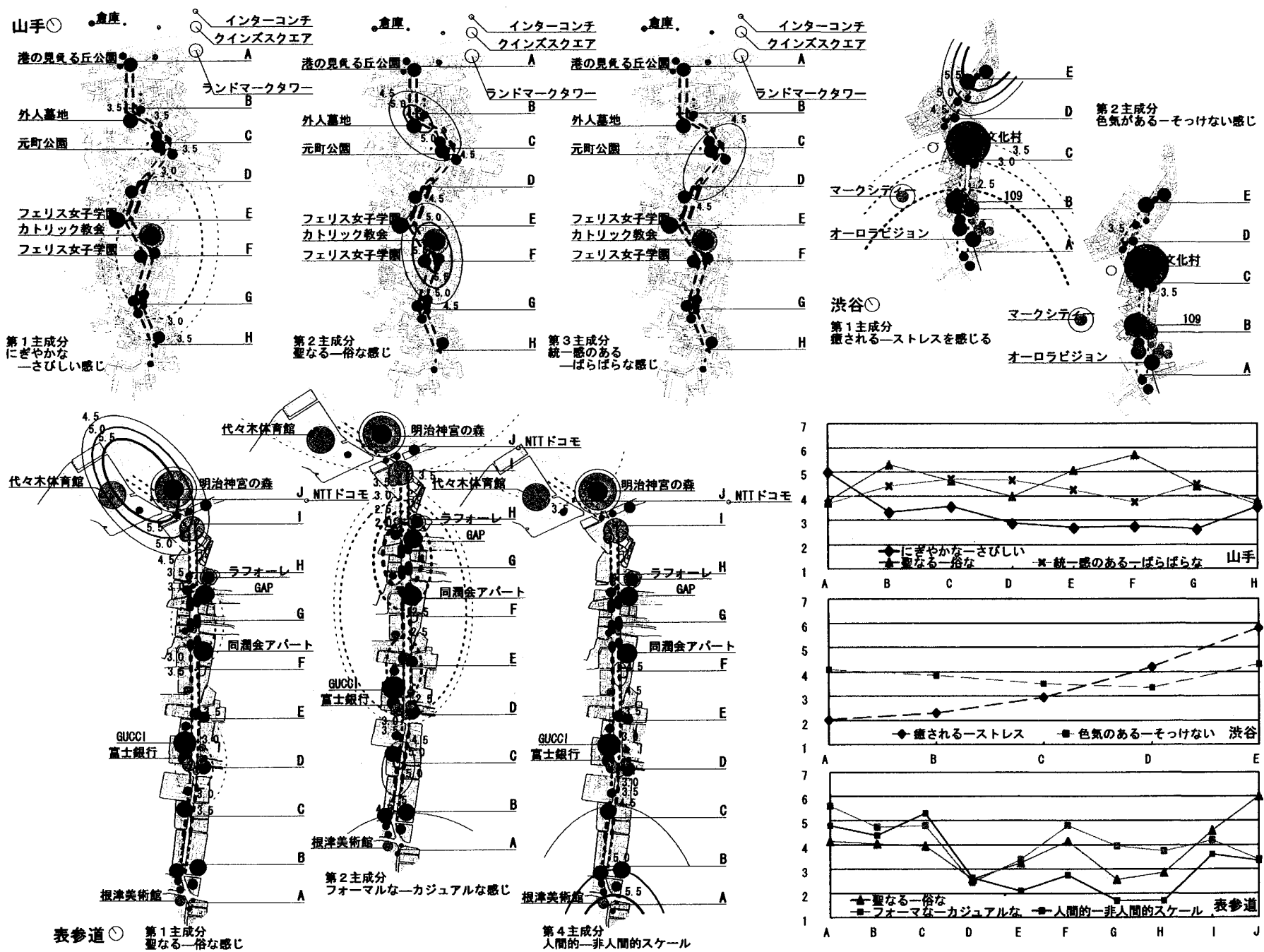

图5 心理量分布图(主成分別)と指摘量ドットマップ図(c) 
のまとまりが形成されている。指摘量ドットマップ図から見ても鎌 倉の街路空間の中で豊かな感じ（評価 $4.5 \sim 6$ ） の雾囲気を生み出す 街路樹というエレメントに加えて、にぎやかな感じ（評価 4.5〜6) を生み出す八幡宮や鳥居、段葛等、歴史的街並みを意識させるエレ メントがシークエンシャルに指摘されることで、目的空間へ近づく に従い、これらの雾囲気が高まり、一筋の参道の八幡宮に向かう兆 しを含んだ「気配」が作られていることがわかる。しかし、E、F 地点で歴史的街並みにそぐわないエレメントである線路が指摘され、 このシークエンシャルな雲囲気が分断している。（第 2）では、G地 点（評価 6）を中心に $\mathrm{E}$ なら J 地点まで〈にぎやかな感じ〉のまとま りが見られる。I、J 地点付近には近代美術館や太鼓橋、お土産店 等が比較的にぎやかな感じで、印象的な雰囲気を作っている（図 6)。 【秋葉原】全体的に見て秋葉原は、Eから $\mathrm{F}$ 地点では印象的な《近》 エレメントが全くなく雾囲気を分断し、(1)秋葉原駅前付近を中心と

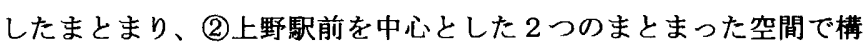
成されている。（第 1）では、Aから F 地点まで〈ストレスを感じる〉 まとまりが見られる。これは、《不特定》エレメントの看板があまり にも印象的なエレメントとして捉えられ、その雾囲気が次の空間ま で挔がりを持って形成しているためである。また、上野公園の緑や 東京文化会館、上野の森美術館などのエレメントが集合として認識 されるK 地点（評価 6）では〈瘾される感じ〉のまとまりを形成し ている。これは、上野公園の緑、Aから J 地点では見られなかった、 ゆとりのある建物配置構成により、開放的な㞣囲気を作りだしたた めである。（第 2) では、K地点（評価 5.5）の上野駅を中心とした 〈親しみのある感じ〉のまとまりが、H地点まで拡がっている。（第 3 ）
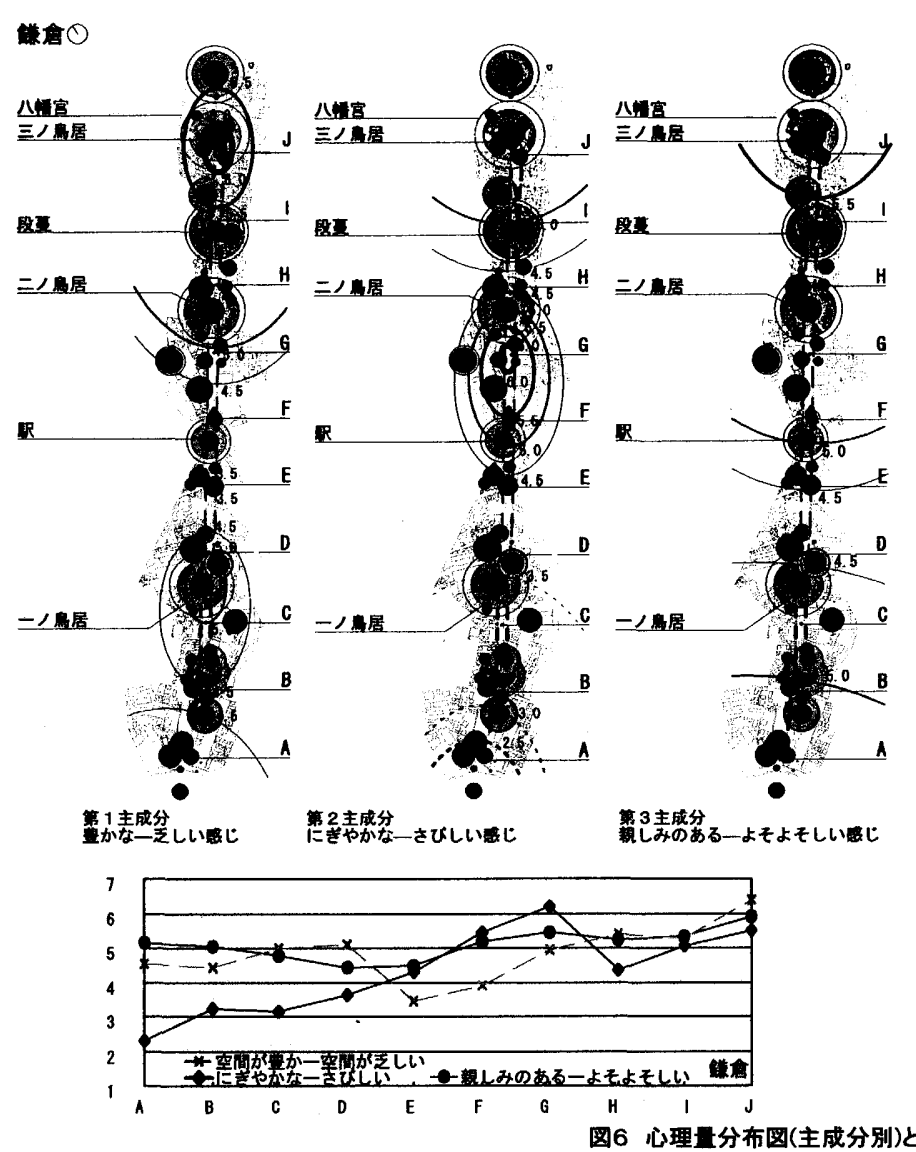

图6 心理量分布図(主成分別)と指摘量ドットマップ図(d)
では、B、G地点（評価 5) を中心とした〈新しい感じ〉のまとまり がある。指摘量ドットマップ図から見ても秋葉原の街路空間の中で、 $\mathrm{B}$ 地点は電気街の中心地で商品広告の看板等の指摘が多く、その影 響が強いと考えられる。G 地点は松坂屋デパート、A B A B 等のア パレル関係の S HO Pが多いためである。また、J 地点（評価 3）は アメヤ横丁等の昔ながらの商店街等のエレメントが多く指摘され、 〈古い感じ〉の雰囲気を作っている(図 6)。

【馬車道】全体的に見て馬車道は、E地点の橋付近を境とし、(1)歴史 地区の A から D地点と、(2)《遠》エレメントの影響を強く感じる $\mathrm{E}$ から G地点の新しい空間の 2 つで構成されている。（第 1 ）では、A 地点（評価 5）の関内駅前を中心に〈緑の多い感じ〉、G地点（評価 2.5）を中心に Eから $\mathrm{G}$ 地点のワールドポーターズ付近は〈緑の少な い感じ〉のまとまりがある。Aから D地点は歴史がある街路空間で 街路樹も計画的に整備された空間であるためといえる。(第2）では、 B地点（評価 3）の関内ホールを中心とした〈カジュアルな感じ〉の まとまり、D地点（評価 5) を中心に〈フォーマルな感じ〉のまとま りを形成している。Aから D地点では西洋風のファサードデザイン を持つ横浜市第二合同庁舎や公団ビル等の《近》エレメントの指摘 が多く、それらがフォーマルな䨌曲気を作っているといえる。（第 3 ) では、A地点（評価 3.5）の関内駅前の銀行等、駅前にありがちなエ レメントが集合として認識されることで〈そっけない感じ〉のまと まりを形成している。（第 4) では全体的に〈健全な感じ〉のまとま りが見られる。しかし、E地点の檑付近は視界が開けているが、間 近にある古びたビルや污れた海水等が空間から健全さを失わせ、雾 囲気を分断する要因になっている（図 7)。

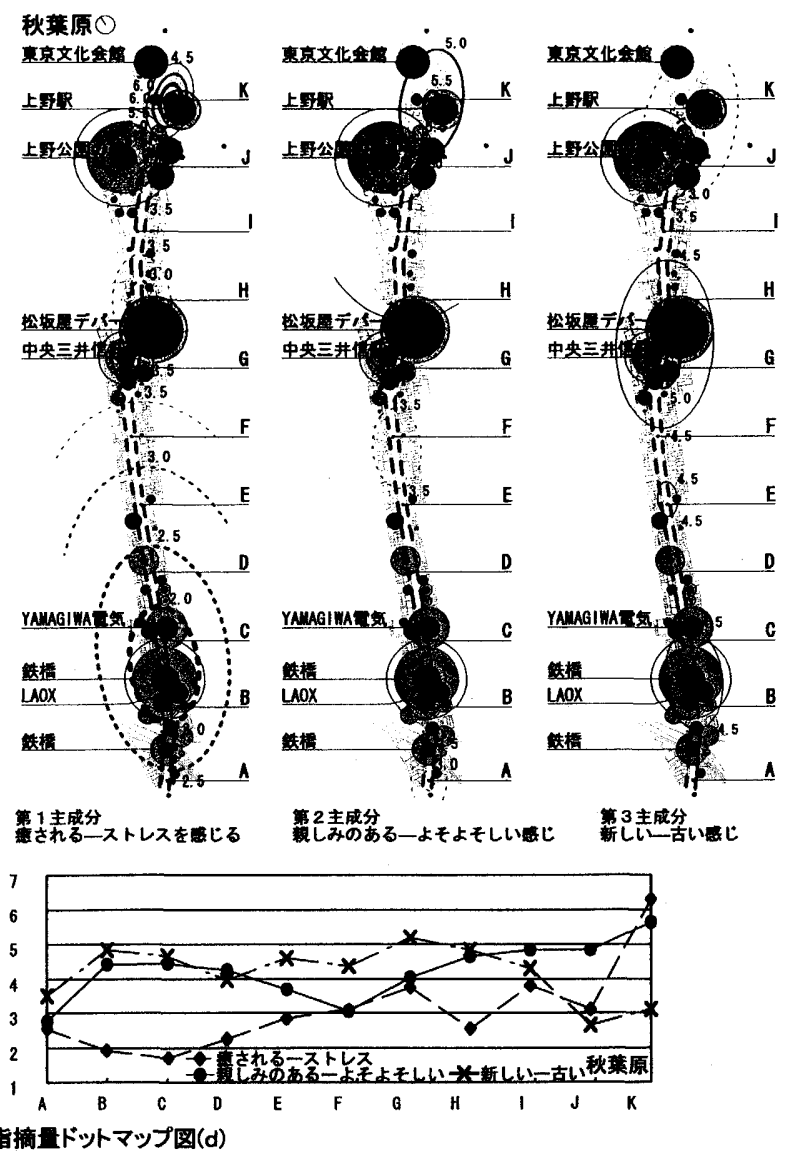


【新宿】全体的に見て新宿は、(1)新宿駅を中心としたまとまり、(2)大 久保方面を中心としたまとまりの 2 つで構成されている。（第 1 ）で は、大きく雰囲気が二極化している。AからC地点（評価 6.5）の新 宿駅側は、看板や街路樹等の《不特定》エレメントで構成され〈に ぎやかな感じ〉のまとまりがある。 D、E地点（評価 2.5）の大久保 方面は、小さな飲み屋街などのエレメントが密集する所では〈さび しい感じ〉のまとまりが見られる。（第2）では、C地点（評価 2.5） を中心に AからD地点まで〈乏しい感じ〉のまとまりが見られる。 指摘量ドットマップ図から見ても新宿の街路空間の中で印象的な新 宿コマ劇場のエレメントが多く指摘されているにも関わらず、その 周辺街路により〈乏しい感じ〉の空間として捉えられている（図 7)。 【巣呞】全体的に見て巣鴨は、(1)巣鴨駅前を中心としたまとまり、(2) とげぬき地蔵尊通りの 2 つまとまりで構成されている。(第 1 ) で は、A、B、E、G地点を中心とした〈ばらばらな感じ〉のまとま りが見られる。A地点（評価 3.5）の巣鴨駅前は、商店街など様々な エレメントが複合的に集合したためであろう。(第 2) では、A地点 （評価 6）を中心にD地点まで〈にぎやかな感じ〉のまとまりが見ら れる。（第 3）では、A地点（評価 5)、Bから G 地点まで〈直線的な 感じ〉のまとまりが見られる。この要因として、商店街のアーケー ド、とげぬき地蔵尊通りを連綍して続くエレメント等が被験者に強 く直線性を感じさせたと考えられる。（第 4) では、D地点（評価 3.5） を中心に小さな〈うっとうしい感じ〉のまとまりがある（図７）。

\section{4. まとめ}

心理評価実験を用いて、前報の指摘法で得られた指摘量ドットマッ プ図と本報で作成した主成分別の心理量分布図を総じて分析を行っ た。この分析をもとに全地区の主成分分析で得られた主要な心理評 価と指摘法実験で得られた《近》《中》《遠》《不特定》のエレメント の指摘量を概観して、第 1 から第 4 主成分で固有值 1 以上の評価が 得られた心理評定尺度、つまり街路の気配を構成する主なエレメン トについて以下に述べる。

(1)にぎやかな感じ・ストレスを感じるは、《近》エレメントである駅、 バス停、オーロラビジョン等や《不特定》ェレメントの看板、人等 のアクティビティを喚起させるエレメントが構成することで生み出 される。(2)さびしい・ばらばらな感じは、《近》ェレメントである住宅、 雑居ビル、飲み屋、公園等の「地」エレメントによりつくられやすい。 (3)健全な感じには、《近》エレメントである住宅地、駅前の広場、オ フィスや《不特定》エレメントの街路樹や緑、人のエレメントが影 響を与えやすい。(4)（空間が）豊かな・さわやかな感じは、《不特定》 エレメントである街路樹や緑、自然的な「図的」エレメント ${ }^{\text {将9) } に ~}$ より雾囲気を与えやすい。(5) (空間が) 之しい感じには、《近》エレ メントであるパチンコ店、高速道路、駐車場等や〈不特定〉エレメ ントである路上駐車の自転車等が影響を与えやすい。(6)人間的スケー ルは、《近》エレメントの住宅や《不特定》エレメントの街路樹等に より影響し、(7)非人間的スケールは、《近》《中》《遠》エレメントで

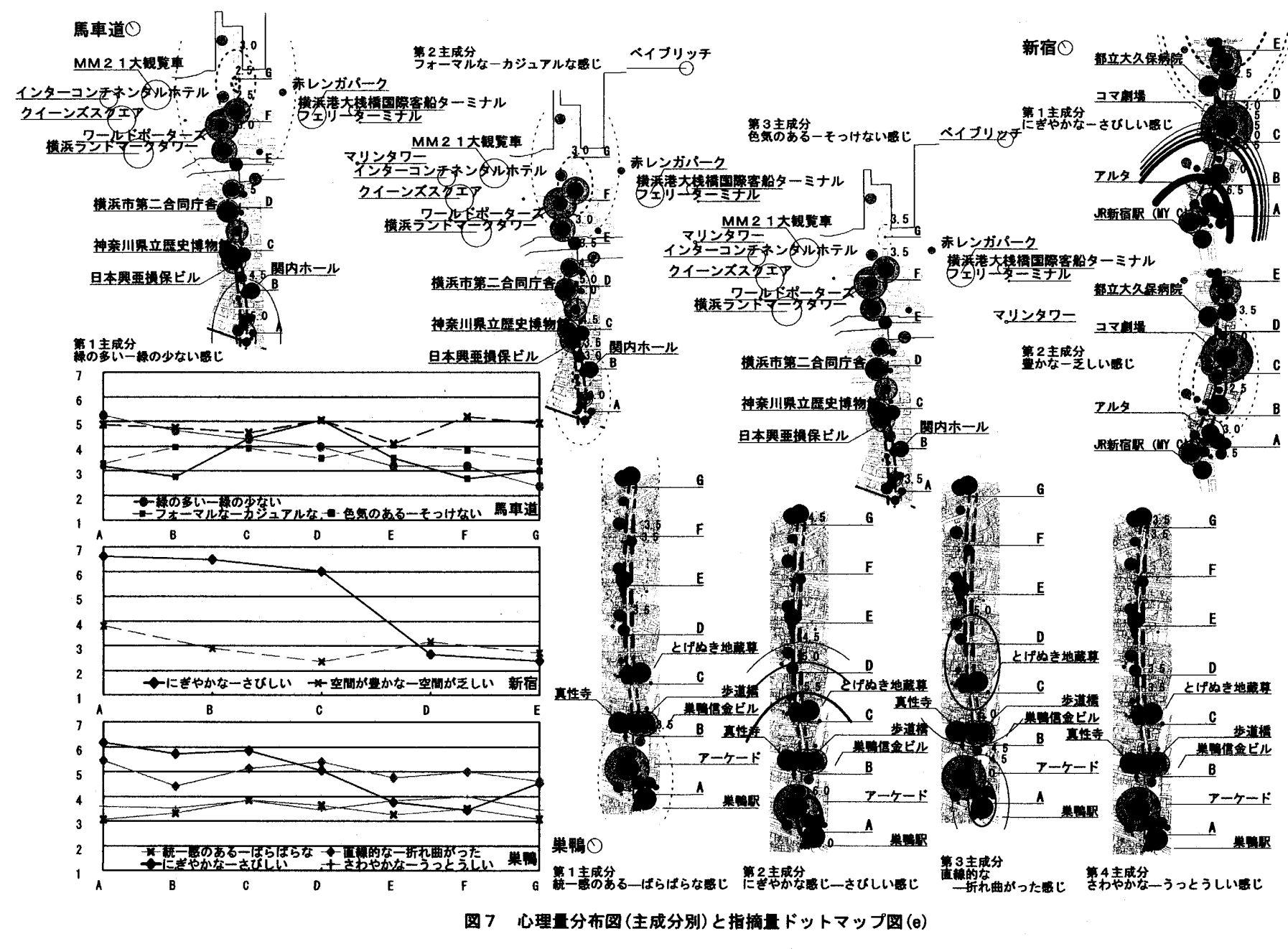


ある東京タワー、高層マンション、高速道路等の象徴的なエレメン トによって醇し出されている。これらエレメントはその近くになく ても、遠距権にあるだけで、非人間的なスケールを生み出している。 (8)癒される感じには、《近》エレメントの住宅や《不特定》エレメン トである緑が影響を与えやすい。(9)期待感のある感じを生み出すに は、《近》エレメントである店や《近》《中》エレメントである鎌倉 の鳥居や《近》《中》《遠》エレメントである東京タワー等の象徵的 なエレメントによって構成される。遠望できるランドマーク等がそ の場の期待感を高めることになる。(10統一感のある感じには、《近》 《中》エレメントである皇居や《不特定》エレメントである明治神宮 の緑、上野公園の緑といった中距離で認識されるエレメントを配す ることで連続した統一感がつくられる。(11聖なる感じには、《近》《中》 エレメントである教会、墓地等や《不特定》エレメントである緑が 影響を与えやすい。(12)俗な・うっとうしい感じには、《近》エレメン トである古いアパート等や《不特定》エレメントである看板が影響 を与えやすい。(13)フォーマルな感じには、《近》《中》エレメントで ある美術館やオフィスビルが影響を与えやすい。(14)ガュアルな感 じには、《近》エレメントである駅、ショップや《不特定》エレメン トである緑が影響を与えやすい。

以上のように、各街路空間において心理評価と指摘エレメントの 関係を詳細に把握し、街路空間の気配を生み出すエレメントを導く ことができた。今後、指摘エレメント 6 タイプと心理評価の関倸に ついて分析を行う予定である。

\section{謝辞}

本研究を進めるに当って、当時東京電機大学建築学科積田研究室 の方々には調查・分析を通して多くの協力を頂いた。ここに記して 梁く感謝いたします。

\section{注}

注 1 ) 指摘されたエレメントの数を指摘数、指摘エレメントの指摘数の総和を 指摘量とし、それぞれ集計した文1)。

注 2 ) 各地区の地点ごとに往路・復路計 20 名分の各エレメントの指摘量を、 これに比例した円で地図上にプロットしたものである゙1）

注 3 )《近》《中》《遠》《不特定》エレメントとは、位置の特定できるものを《特定》 エレメントとして、実鸦地点より直径 $200 \mathrm{~m}$ 以内（地点）のものは《近》、 直径 $200 \mathrm{~m}$ 以上 $600 \mathrm{~m}$ 以下（地点前後）のものは《中》、600 m以

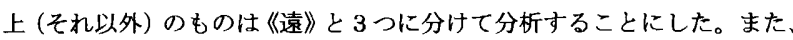
街路樹や看板の様に、正確な位置を特定できないものを《不特定》エレ メントとして分類した ${ }^{\text {11 }}$

注 4 ) 指摘エレメント構成の 6 タイプ 前報文1) で得られた《近》《中》《遠》《不 特定》の指摘量の割合を類型度としてクラスター分析 (最長距離法)を行っ た結果、それらの割合から得られた 1 1 E 6 の計 6 タイプのエレメン 卜構成として類型化したもの。

注 5 ) 既往研究文文 2) とは異なり、本研究では、教会、寺院等が存在する街路 空間を対象とし、これらの雲囲気を捉えるため「聖なる感じ一俗な感じ」 の心理評定尺度を追加した。さらに、本対象地区では慗華街から住宅街 など、異なる用途の複合した街路を対象としているため、これらのシー クエンシャルな雾囲気の違いを捉えるために「疮される感じーストレス を感じる」「健全な感じ一怪しげな感じ」「色気のある感じーそっけない 感じ」人間的スケールー非人間的スケール」の心理評定尺度を加えた。

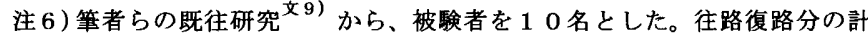
20 名分のデータが得られている。また、各被験者の評価が概ね正規分 布していることが判明したため、今回は 10 名で有効とした。

注 7 ）往路と復路との同一地点での心理評価に若干の違いがある調查地点も あったが、総じて、その地点での心理評価と今回はみなすことにした。

注 8 ) 空間の券囲気は、街路の調查対象地点を含む周辺の雾囲気を総じたもの として受け止められ、さらにシークエンシャルに慗がって構成されてい ると考える。ここでは、平面図上に心理の変化を分かりやすく表現する ことを目的としてこの方法をとった。

注 9 )「図」エレメントとは指摘率が高く、特定できその空間を印象付けるエレ メントである。「地」エレメントとは、図」エレメントとは逆に指摘率 が低く、特定できないエレメント・テクスチャーなどである。「図的」エ レメントとは、街路樹のように複数あって、特定できないエレメントで、 指摘率が $25 \%$ 以上のもの。街路の質の高さや、開放感と関倸するもの である文5)

\section{参考文献}

文 1 ) 穔田洋、関戸洋子、菅原網治：指摘量分析によるエレメントの特性とエ レメント構成の)類型化一街路空閒における「気配」の研究（その1）一、 日本建勧学会計画系論文集 No. 583、pp. $47 \sim 52 、 2004.9$

文 2 ) 樌田洋 : 都市空間の構成と意識構造の相関に関する研究、東京大学学位 論文 1994.3

文 3) 船越徽、糟田洋: 街路空間における空間意識の分析（心理量分析）一街

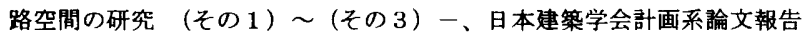
集 No. 327、pp. $100 \sim 107 、 1985.5$ No. 364、pp. $102 \sim 111 、 1986.6$ No. $378 、$ pp. $49 \sim 57 、 1987.8$

文 4) 㮴田洋：都市的オープンスペースの空間意識と物理的粡成との相関に 関する研究、日本建築学会計画系論文報告集 No. 451、pp. 145 154 1993.9

㮴田洋、廣野勝利 : アーバンコンプレックスにおける空間意識と空間構 成要素の)相関分析ーアーバンコンプレックスの研究（その1）一、日本 建築学会計画系論文集 No. 557、pp. $203 \sim 211 、 2002.7$

文 5) 楮田洋：心理量分析と指摘量分析による街路空間の「図」と「地」の分 析一街路の空間構造の研究（その1）－、日本建勧学会計画系論文集 No. $554 、$ pp. $189 \sim 196 、 2002.4$

積田洋：外部空間の構造を捉える一街路空間の図と地一「空間計画学、 日本建築学会 [編 $]$ 井上書院 2002.5.10

女6) 松本直司、谷口沉邦、池田徹 : 住宅地における建築群の構成計画に関す る基礎的研究一建築空閏構成の計画の研究（その1）一、日本建築学会 大会学術梗概集 pp. 1033 1034、1976. 10 松本直司：縮尺模型で実酫する一住棟の配置構成一建筑・都市計画のた めの空間学日本建築学会 [編]、井上書院 1990.11 .10

文 7 ) 船越徹、積田洋、清水美佐子: 参道空閒の分節之空間構成要素の分析一（そ 0) 1)、日本建築学会計画系論文報告集 No. 384、pp. $53 \sim 62 、 1988.2$

文 8 ) 志水英樹、鈴木信弘、塩田洋 : 参道空閒における視觉・記憶構造に関す る研究、日本建筑学会計画系論文集 No. 456、pp. $93 \sim 100 、 1994.3$

女 9 ) 鈴木弘栈、積田洋、栗生明 : 断面想起法による空間認知と空間意識の相 関分析ーランドスクープ -アーキテクチャの断面構成に関する研究（そ の 2）－、日本建築学会計画系論文集 No. 601、pp. $95 \sim 101 、 2006.3$ 積田洋、関根智則、伊藤奈津子 : ランドスケープーアーキテクチュアに おける軸線の構成の研究、日本建築学会計画系論文集 N0.602 PP. 59 $\sim 64$ 2006. 4 他

(2005年 7 月 9 日原稿受理, 2006 年 6 月 6 日採用決定 